\title{
IN THE MUSEUM
}

\section{A J Ryan (University of KwaZulu-Natal)}

Two Egyptian artefacts from the first millennium BC have recently been acquired by the Museum of Classical Archaeology at the University of KwaZulu-Natal, courtesy of a kind donation by Miss Joan Law. At a time when academia in South Africa is placing considerable emphasis on African-oriented scholarship, it is appropriate that the museum has on display a large selection of small Egyptian artefacts dating from as early as the $4^{\text {th }}$ millennium BC. These items are of particular interest for teaching as they reflect a variety of different aspects of Egyptian life.

The first item is a colourful and brightly painted fragment of cartonnage ${ }^{1}$ from the exterior of an anthropoid sarcophagus. ${ }^{2}$ Cartonnage on sarcophagi and mummies often depicts scenes from the book of the dead. However, it is difficult to interpret our piece since most of the icons and symbols are barely decipherable. The only immediately recognisable figure is the lower portion of the vulture goddess, Nekhbet, which dominates the top half of the fragment. The view is frontal and only her legs, lower belly and a portion of her outstretched right wing are visible. It has been argued that the Egyptians did not mention the true names of their gods whom they identified instead by pronominal epithets. ${ }^{3}$ Thus Nekhbet is not strictly the name of the divinity but a geographical epithet denoting her origin as the patron of the city Nekheb, now el Kab, in southern Egypt. Although Nekhbet is in origin a local divinity, she comes to represent the whole of Upper Egypt and from as early as the first dynasty (2920-2649 BC) her icon, the vulture, appears together with the cobra of the goddess Wadjet in the Pharaonic crown. The two goddesses together symbolise the Pharaoh's authority over both kingdoms of Egypt and as nebti ("the two ladies") form the second part of the formulaic titulary of the Pharaoh. In addition to her role as the patron of El Kab she is also a goddess of childbirth and the protection of mothers. It is not surprising therefore that Greeks identified her with Eileithyia, the Cretan/Greek goddess of childbirth, and referred to Nekheb, her home town, as Eileithyiaspolis. Nekhbet occasionally appears in frontal pose outstretching her wings in a gesture of protection on pectorals ${ }^{4}$ and coffins $^{5}$ and she probably serves a similar function here.

Our piece may be dated to the $21^{\text {st }}$ dynasty (1070-945 BC), which marked the beginning of the Third Intermediate Period (1070-712 BC). Egypt was in a state of turmoil following the death of the last Ramesside King, Ramses XI. By this stage the theocracy, ${ }^{6}$ which had always enjoyed considerable influence, particularly in Upper Egypt, had eroded the power of the pharaoh to the extent that Upper Egypt was virtually under the complete control of the priesthood. After the death of Ramses XI, Upper Egypt continued to be ruled by the priesthood while the vacuum left in the north allowed the obscure Smendes I to claim the

1. This papier-mâché-like cardboard was usually made from layers of moistened linen pasted together with adhesive and coated with a layer of stucco.

2. Durban 2005.50: 108 mm x 96 mm; figure 1; excavated near Luxor.

3. For example, by Dunand and Zivie-Coch (2002:25-7).

4. As she does on two pectorals in the Cairo Museum - those of Sunesret III (1878-1841 BC), Aldred (1962:52 no. 72); and Amenemhet III (1842-1797 BC), Aldred (1962:52 no. 73).

5. Nekhbet also appears stretching out her wings in protection on the chest of a $17^{\text {th }}$ dynasty sycamore rishi coffin in the British Museum, EA 52951, Robins (1997:figure 126).

6. The priesthood of Amun, which had it's seat of power in Thebes, in southern Egypt. 
throne and found the $21^{\text {st }}$ dynasty. His reign, and those of his descendants, was characterised by the theocracy's nominal recognition of the dynasty as legitimate pharaohs while in reality the pharaoh had virtually no control over the south. Although there were tensions between the north and the south during this period, there is evidence of cordial diplomatic relations between the pharaoh and the priesthood, even to the extent that Smendes' daughter Isiemkheb married Menkheperre, high priest of Amun, and the last of the $21^{\text {st }}$ dynasty kings, Psussenes II, was apparently both pharaoh and high-priest. An important change in burial customs in Thebes during this period was the abandonment of private tomb chapels and the paintings that had traditionally appeared on the walls of the tombs were now painted directly on the coffins themselves. While the $21^{\text {st }}$ dynasty was a period of political instability, the art of the time did not reflect this and the painted coffins from the period are among the best examples from antiquity. Our piece, although decorated by an artist of modest ability, still reflects this artistic spirit in the vibrancy of its colours.

After the $20^{\text {th }}$ dynasty, Egypt is never truly unified under Egyptian rule. Following the death of Psussenes II in 945 BC, Egypt comes under Libyan rule through the marriage of Psussenes II's daughter with the Libyan prince Shoshenq I. Although a strong ruler, he failed to secure lasting unity of Egypt, which again fragmented after his death. Successive rulers, many foreign, vied for power during the $23^{\text {rd }}$ to $30^{\text {th }}$ dynasties, culminating in the invasion of Egypt by the Macedonians/Greeks under Alexander the Great, and the establishment of the Ptolemaic dynasty. This period saw the Hellenisation of Egypt and some syncretism of Greek and Egyptian religions and cults.

The second of the museum's recent acquisitions is dateable to very late in the Ptolemaic period. It is a wooden fragment of a sarcophagus ${ }^{7}$ with a painted column of hieroglyphics surmounted by a recumbent Anubis to right in jackal form ${ }^{8}$ carrying the pharaonic symbols of power, the crook and flail. The hieroglyphics appear to resemble an offering formula to Osiris, which is found on a variety of artefacts including sarcophagi. Recognisable is an attempt at rendering the opening of the formula "A gift that the king gives to Osiris, foremost..." which is illustrated in figure 3 together with a clearer representation of the intended hieroglyphics. The name of Osiris is barely legible, the second eye below the name of Osiris is superfluous, and the formula stops making any sense after "foremost". The person who wrote the offering formula may have been illiterate, although it is possible that our difficulty in translating the hieroglyphics owes something to the lateness of the piece and to the lack of care and attention paid by the scribe. Despite the problems with the translation, the piece is a welcome addition to the museum's small collection of objects relating to ancient writing. This currently includes a small Sumerian clay tablet with a Cuneiform inscription, ${ }^{9}$ a Hellenistic era papyrus, ${ }^{10}$ an inscribed rim of a lip-cup by the Centaur painter, ${ }^{11}$ a Roman terracotta lamp, ${ }^{12}$ and an assortment of writing equipment from the Roman period.

The two pieces here presented are the latest additions to a large collection of Egyptian pieces on display at the Museum of Classical Archaeology. That these pieces are in display beside artefacts from Greece and Rome is apposite in an institutional environment which

7. Durban 2005.51: $495 \mathrm{~mm}$ x $170 \mathrm{~mm}$; figure 2 .

8. Anubis, an important god of the underworld and the judge of the dead, may appear either as a jackal or as a jackal-headed man.

9. Durban 1999.40; Mackay (1999:165, figure 2).

10. Durban 1996.42; Mackay (1997:167, figure 2).

11. Durban 1983.9; Mackay (1993:152, figure 2).

12. Durban 1994.38; Mackay (1996:173,figure 2). 
seeks to define African scholarship and, by juxtaposition, illustrates that the depth of Africa's antiquity is easily comparable with that of the Graeco-Roman world. Most of the Egyptian pieces on display are on loan from the Durban Art Gallery, the Local History Museum and the Natural Science Museum, and through generous donations like those from Miss Law, the Museum's own collection is starting to grow.

\section{BIBLIOGRAPHY}

Aldred, C 1962. The development of ancient Egyptian art from 3200 to 1315 BC. London: Alec Tiranti.

Baines, J, Lesko, L H \& Silverman D P 1991. Religion in ancient Egypt: Gods, myths and personal practice. Ithaca and London: Cornell University Press.

Dunand, F \& Zivie-Coche, C 2002. Gods and men in Egypt: 3000 BCE to 395 CE. Ithaca and London: Cornell University Press.

Mackay, E A 1993. In the museum Scholia 2:149-150.

Mackay, E A 1996. In the museum Scholia 5:171-174.

Mackay, E A 1997. In the museum. Scholia 6:166-167.

Mackay, E A 1999. In the museum. Scholia 8:164-166.

Robins, G 1997. The art of ancient Egypt. Cambridge, MA: Harvard University Press. 


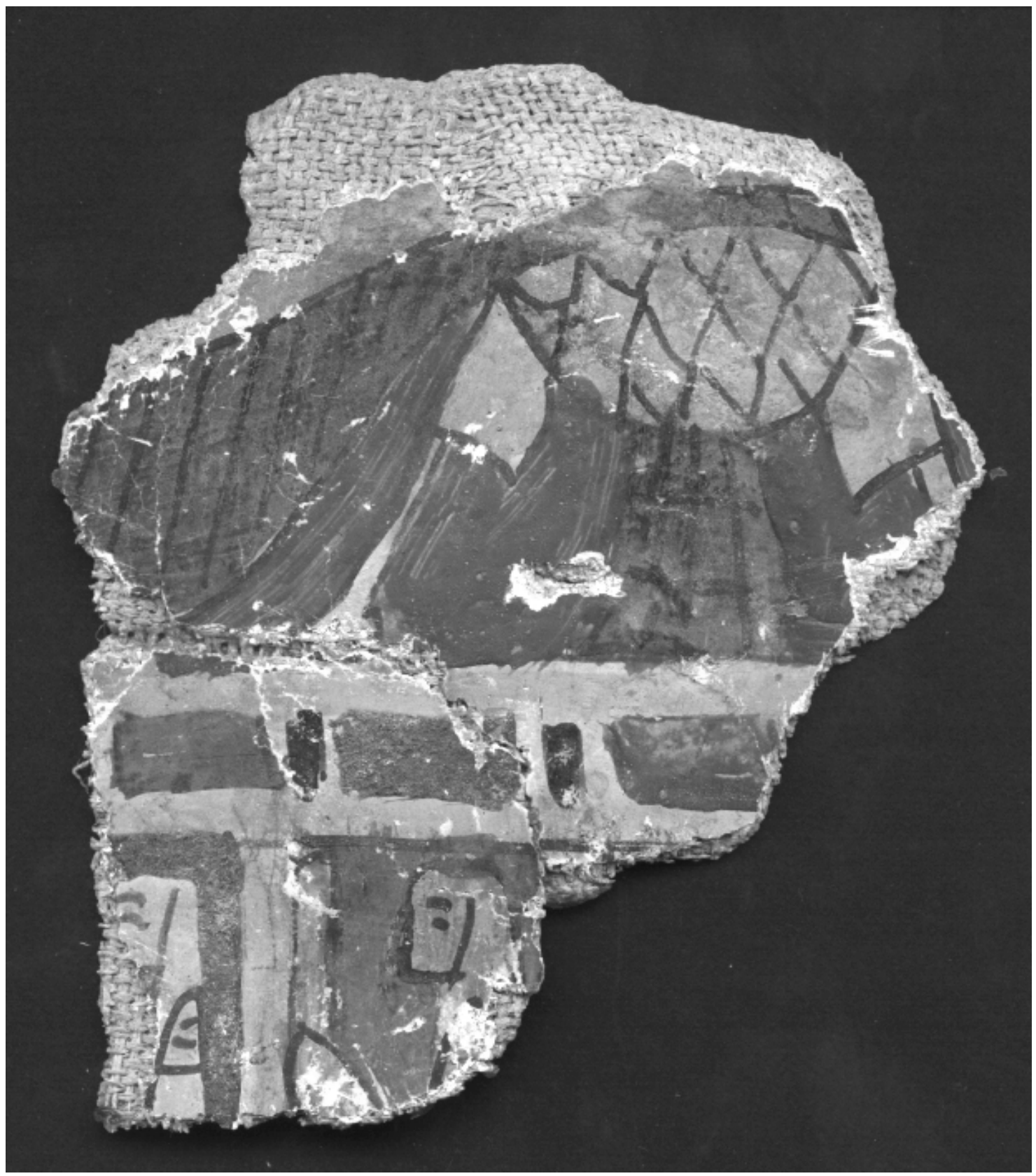

Fig. 1: Durban 2005.50. A cartonnage fragment from a $21^{\text {st }}$ dynasty sarcophagus. 


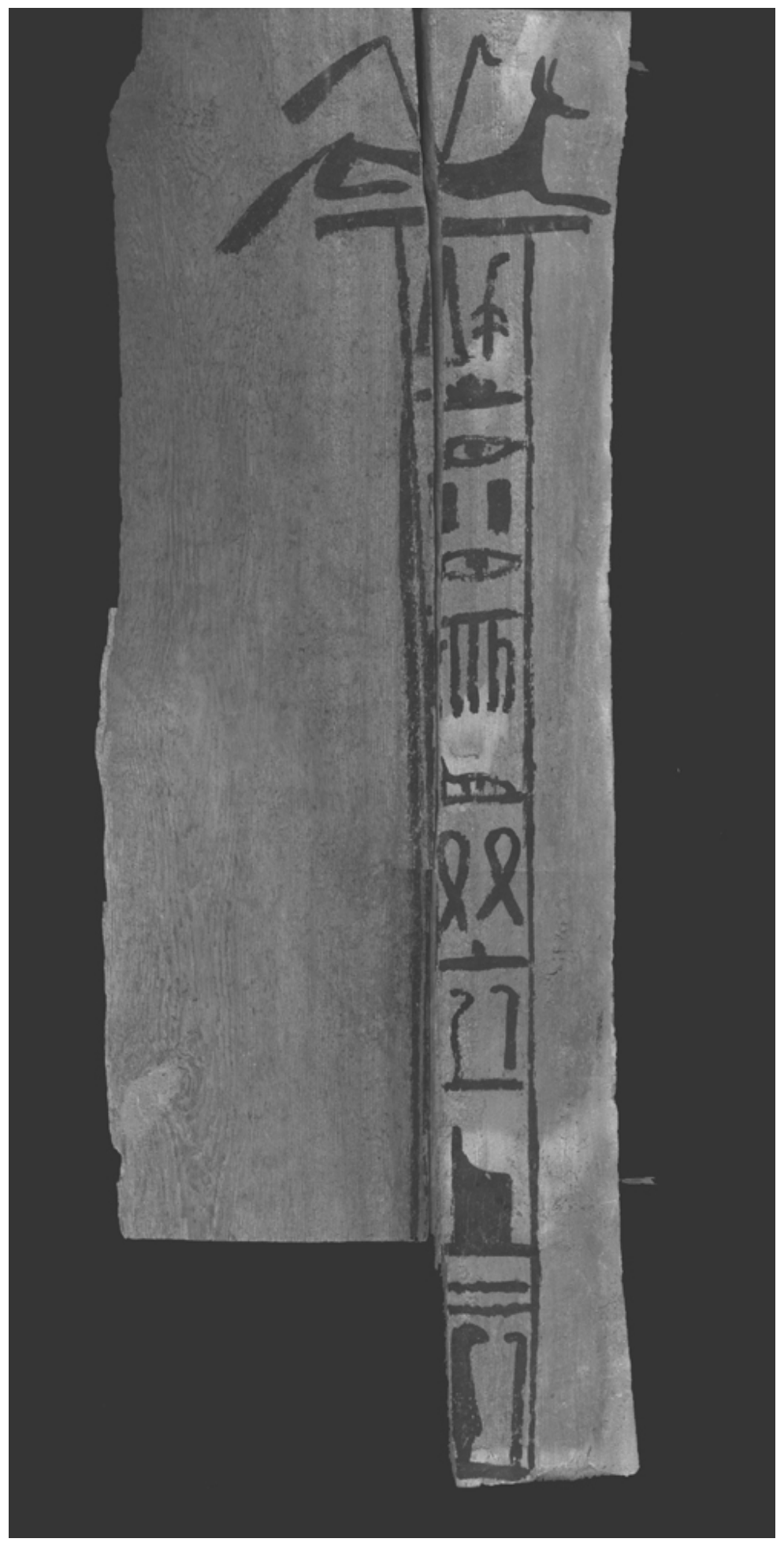

Fig. 2: Durban 2005.51. A panel from a sarcophagus featuring Anubis and hieroglyphics. 


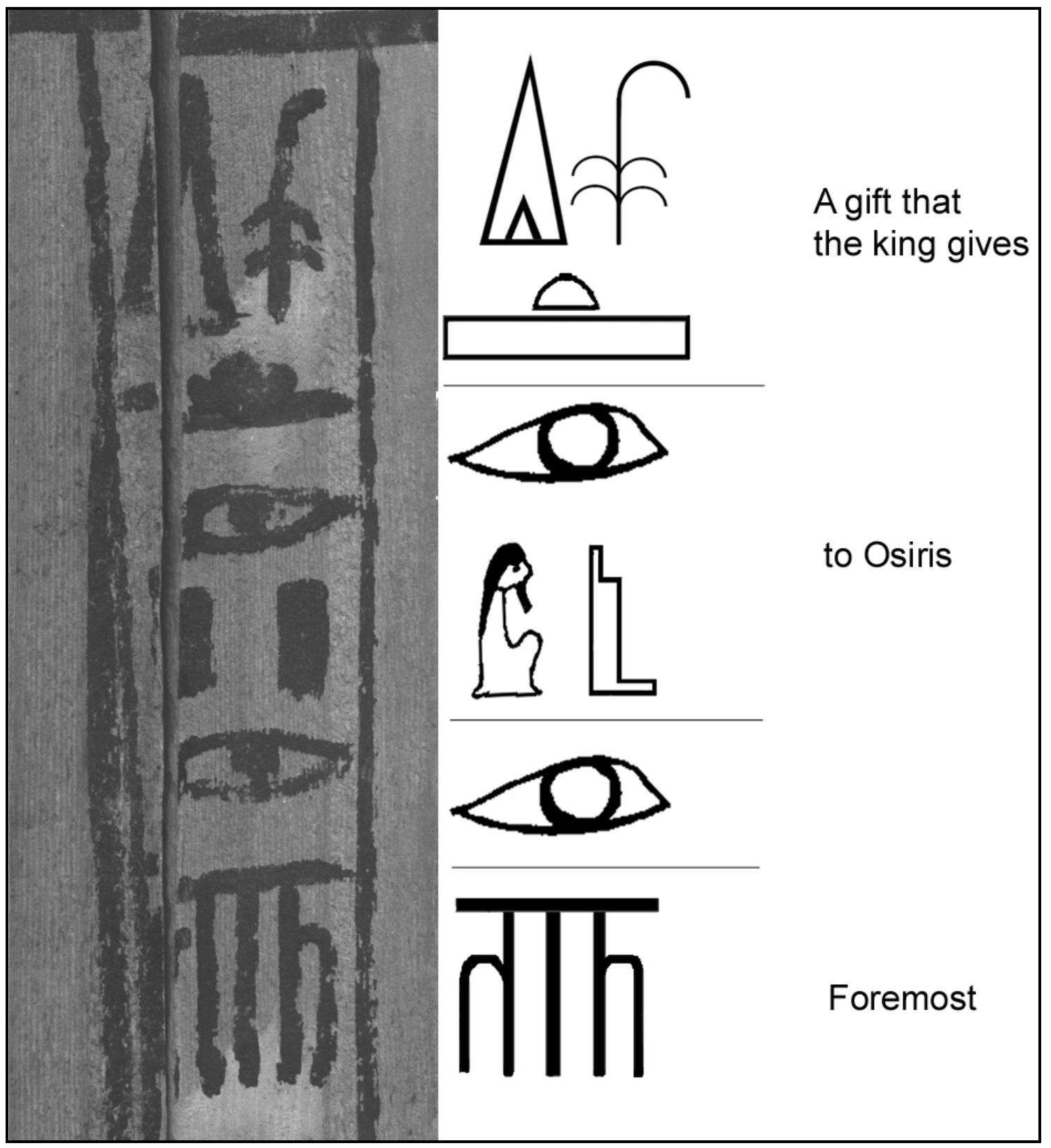

Fig. 3: Detail of Durban 2005.51 together with translation. 